Biol. Neonate 1979;36:I-IV

\title{
Contents, Vol. 36, 1979
}

\section{No. 1-2}

Original Paper

Frank, L. and Roberts, R.J.: Effects of Low-Dose

Prenatal Corticosteroid Administration on the

Premature Rat 1

Corbet, A.J.S.; Ross, J.A.; Beaudry, P.H., and Stern, L.: Assessment of Ventilation-Perfu-sion

Inequality by aADfj in Newborn Infants 10

Timor-Tritsch, I.E.; Dierker, L.J.; Hertz, R.H.;

Zador, I., and Rosen, M.G.: Human Fetal

Respiratory Movements: a Technique for

Noninvasive Monitoring with the Use of a

Tocodynamometer 18

Merat, A.; Sajjadi, S., and Dickerson, J.W.T.:

Effect of Development of the Gangliosides of

Rabbit Brain 25

Cabello, G.: Neonatal Changes in the Plasma

Levels of Cortisol, Cortisone and Aldosterone

in the Calf 35

Conde, C; Mazzá, M.; Almar, J.; Seijo, G., and

Ballabriga, A.: Organic Acids in Urine from

Preterm Infants 40

Del Principe, D.; Gabriotti, M.; Mastracchio, F.; Menichelli, A., and Giardini, O.: Malonyldialdehyde Formation, Oxygen Consumption,

Fatty Acid Composition in Newborn Platelets

Stimulated by Thrombin

O'Kelly, J.C. and Wallace, A.L.C.: Plasma Thy

roid Hormones and Cholesterol in the New born of Genetically Different Types of Cattle in a Tropical Environment 55

Randall, G.C.B.: Studies on the Effect of Acute Asphyxia on the Fetal Pig in utero 63 Gootman, N.; Gootman, P.M.; Crane, L.A., and Buckley, B.J.: Integrated Cardiovascular Responses to Combined Somatic and Visceral Afferent Stimulation in Newborn Piglets ... 70 Callikan, S. and Girard, J.: Perinatal Develop ment of Gluconeogenic Enzymes in Rabbit Liver 78 
Hietanen, E. and Hartiala, J.: Developmental Pattern of Pulmonary Lipoprotein Lipase in Growing Rats 85

Thomasson, B.; Kero, P.; Länsimies, E.; Toikkanen, S., and Välimäki, I.: Pulmonary Aera tion after Unilateral Fetal Ligation of Pul monary Artery in Neonatal Rabbits 92 Wamberg, S.; Engel, K., and Kildeberg, P.: Bal ance of Net Base in the Rat. V. Effects of Oral Ammonium Chloride Loading 99 Zimmermann, T.; Hummel, L.; Möller, U., and Kinzl, U.: Oxidation and Synthesis of Fatty Acids in Human and Rat Placental and Fetal Tissues 109

No. 3-4

Noble, R.C.; Shand, J.H., and Bell, A.W.: Fetal to Maternal Transfer of Palmitic and Linoleic Acids across the Sheep Placenta 113 Pernollet, M.G.; Devynck, M.A.; Macdonald, G.J., and Meyer, P.: Plasma Renin Activity and Adrenal Angiotensin II Receptors in Fetal, Newborn, Adult and Pregnant Rabbits .... 119 Tan, K.L.; Jacob, E.; Chua, K.S., and Woon, K.Y.: Phototherapy and Neonatal Liver Func tion 128

Djaldetti, M.: Hemopoietic Events in Human Embryonic Spleens at Early Gestational

Stages 133

Jirsová, V. and Hodr, R.: Phototherapy: the Cause of Increased Enterohepatic Circulation of Bilirubin in Newborn Infants? 145

Mulloy, A.L.; Keen, S.J., and Malven, P.V.: Ab sorption of Orally Administered Bovine Prolactin by Neonatal Rats 148 Klepac, R. and Milkovié, K.: Fetal Rat Adrenal Growth and Steroidogenesis in vitro after Maternal Dexamethasone Treatment 154 Kloosterboer, H.J.; Faassen, H. van; Stoker-de Vries, S.A., and Hommes, F.A.: Effect of Cyclic Nucleotides on Weight of Gastro-cnemius and Creatine Kinase Activity after Denervation of Muscle in Young Rats .... 160

IV

Contents

Ferm, V.H. and Ferm, R.R.: Teratogenic Interaction of Hyperthermia and Vitamin A1 . . 168 Yoshioka, T.; Suigue, A.; Shimada, T., and Utsumi, K.: Superoxide Dismutase Activity in the Maternal and Cord Blood 173 
Vedvick, T.S.; Wheeler, S.A., and Koenig, H.M.:

Heterogeneity of Fetal Hemoglobin in Severe

$\alpha$-Thalassemia

181

Pollak, A.; Widness, J.A., and Schwartz, R.:

'Minor Hemoglobins': an Alternative Ap

proach for Evaluating Glucose Control in

Pregnancy 185

Prïbylová, J. and Kozlová, J.: Glucose and Galac-

tose Infusions in Newborns of Diabetic and

Healthy Mothers

193

álebodziński, A.B.: Metabolic Response to

Thyroxine in the Newborn Pig 198

Kendall, K.; Jumawan, J., and Koldovský, O.: Development of Jejunoileal Differences of

Activity of Lactase, Sucrase and Acid B-Galac-tosidase in Isografts of Fetal Rat Intestine . 206

Molnár, D.; Soltész, G., and Mestyán, J.: The

Metabolic Effects of Cold Exposure in the

Newborn Rabbit 215

Schultz, K.; Soltész, G; Molnár, D., and Mestyán, J.: Effect of Hypothermia on Plasma

Metabolites in Preterm Newborn Infants with Particular References to Plasma Free Amino Acids 220

No. 5-6

Meinel, B.; Bode, J.C; Koenig, W., and Richter,

F.-W.: Contents of Trace Elements in the

Human Liver before Birth 225

Olusi, S.O.; Oke, O.L., and Odusote, A.: Effects

of Cyanogenic Agents on Reproduction and

Neonatal Development in Rats 233

Parker, R.O.; Williams, P.E.V.; Aherne, F.X., and

Young, B.A.: Postnatal Development of

Cardiac Distribution in the Pig 244

Greizerstein, H.B. and Abel, E.L.: Electrolyte

Composition of Fetuses, Placentas, and Mater

nal Plasmas during the Last Trimester of

Gestation in the Rat 251

Lee, J.C. and Downing, S.E.: Effects of Anemia

and Growth Retardation on Respiratory Ac

tivity in the Piglet 255

Marlot, D. and Duron, B.: Postnatal Maturation

of Phrenic, Vagus, and Intercostal Nerves in

the Kitten 264

Lapointe, G. and Nosal, G: Saccharin- or Quinine-Induced Changes in the Rat Pups following

Prolonged Ingestion by the Dam . 273

Lubec, G. and Coradello, H.: Urinary Excretion of Glomerular Basement Membrane Antigens in

Premature Infants and the Newborn .... 277

Johanson, C.E.: Distribution of Fluid between

Extracellular and Intracellular Compartments 
in the Heart, Lungs, Liver and Spleen of

Neonatal Rats 282

Tapanainen, J.; Penttinen, J., and Huhtaniemi, I.:

Effect of Progesterone Treatment on the

Development and Function of Neonatal Rat

Adrenals and Testes 290

Shand, J.H. and Noble, R.C.: $\Delta 9-$ and $\Delta 6$-De-

saturase Activities of the Ovine Placenta and

Their Role in the Supply of Fatty Acids to

the Fetus 298

Armenti, V.T. and Johnson, E.M.: Effects of

Maternal Hypervitaminosis A on Perinatal Rat

Lung Histology 305

MacDonald, M.J.; Kowalchyk, J.A.; Ames, L.A., and Bentle, L.A.: Development of Phosphoenolpyruvate Carboxykinase Ferroactivator in Fetal and Young Rats and Guinea Pigs .... 311

Berger, M.; Jean-Faucher, C; De Turckheim, M.;

Veyssière, G., and Jean, C.: Effect of Lu-

teinizing Hormone-Releasing Hormone on

Plasma Testosterone in Immature and Adult

Male Rabbits 321

Author Index 327

Subject Index 329 